\title{
PENGATURAN ADVOKASI TERHADAP HAK-HAK PENYANDANG DISABILITAS TERHADAP DISKRIMINASI DI BIDANG PENEGAKAN HUKUM
}

Oleh:

\section{Ni Komang Sutrisni ${ }^{1}$}

\begin{abstract}
Human Rights is the rights of human beings are naturally without exception and a privilege for the group, as well as the level of a particular social group. These rights are freedom speech with freedom from all forms of oppression that must be upheld, not only by each individual of a State that recognizes the existence and respect of Human Rights itself, but must also be guaranteed by countries without any exceptions, including persons with disabilities in dealing with legal issues.This study used normative research for examining the principles and rules of law by using the legislation approach, and case-based approach. The regulation is regarding human rights in general stipulated in the Constitution Republif of Indonesia 1945, Act 39 of 1999 on Human Rights, Law No. 4 of 1997 on Persons with Disabilities, Law 19 of 2011 on the Ratification of Convention on the Rights of persons with Disabilities, International Covenant on Civil and Political Rights (ICCPR). The right to non-discriminatory treatment as a continuation of the right to equal treatment before the law for persons with disabilities can be realized through the exercise of the right to a fair trial. All such regulations prohibit all forms of discrimination and guarantee to all persons equal and will be effective protection against discrimination on any basis.
\end{abstract}

Key Word : Advokacion, persons with disabilities, discrimination, law enforcement

\section{PENDAHULUAN}

\subsection{Latar Belakang}

Bangsa Indonesia adalah negara yang berdasarkan atas hukum. Setiap tindakan dalam pemerintahan maupun perlakuan terhadap warga negara Indonesia dilakukan berdasarkan atas hukum sebagai rujukan petama dalam penyelenggaraan

Mahasiswa Magister (S2) Ilmu Hukum Universitas Udayana, Denpasar, Bali, Alamat:Br.Munduk Lampah Desa Sukawana Kec.Kintamani Kab.Bangli, email: komangsutrisni91@gmail.com pemerintahan serta dalam rangka menjamin kehidupan masyarakat Indonesia. Persoalan yang paling penting dalam negara hukum ialah adanya pengakuan serta perlindungan terhadap hak-hak asasi manusia khususnya dalam bidang penegakan hukum. Persoalan yang berkaitan dengan perbuatan yang dilarang dalam suatu peraturan tidak hanya dilanggar oleh seseorang yang memiliki keadaan mental dan fisik yang sempurna, akan tetapi realitasnya menunjukkan bahwa pelanggaran demikian dapat saja dilakukan oleh seseorang yang memiliki keterbatasan 
dari segi fisik maupun psikis atau yang lebih dikenal dengan seorang penyandang cacat atau disabilitas. Kecenderungan akses yang lebih mudah didapatkan oleh seseorang yang memiliki kelebihan dari segi fisik maupun psikis dalam mengahadapi kasus hukum dalam bentuk penanganan kasus yang cepat dibandingkan dengan penyandang disabilitas yang menghadapi kasus hukum, aparat penegak hukum cenderung tidak memproses kasus yang dialami oleh penyandang disabilitas.

Pada hakikatnya semua orang sama dimata hukum tidak dikecualikan dalam keadaan apapun untuk memperoleh keadilan yang sama dalam berbagai bidang kehidupan termasuk dalam bidang penegakan hukum. Dalam ranah kehidupan sosial yang lebih luas, kesulitan partisipasi sosial dan ketidaksetaraan sosial yang terjadi pada individu dengan disabilitas dikesampingkan dalam berbagai bidang kehidupan. Ketika seseorang tidak dapat bekerja, sulit diterima bergaul secara wajar, tidak dapat diterima belajar disekolah karena yang dilihat adalah seseorang tersebut cacat, tidak mampu, dan perlu direhabilitasi. ${ }^{2}$ Persoalan tersebut seolah-olah diakui dalam berbagai kebijakan peraturan perundang-undangan di Indonesia yang mengutarakan apa yang dimaksud dengan penyandang disabilitas. Pengaturan tersebut menempatkan kecacatan atau kelainan fisik atau mental sebagai penyebab hambatan untuk beraktivitas atau hidup sebagaimana layaknya. Artinya menempatkan permasalahan disabilitas sebagai permasalahan individu yang cukup membutuhkan penanganan individu saja. Tidak mengeherankan jika kemudian terdapat peraturan yang menempatkan disabilitas sebagai masalah yang tidak dapat diterima.

Pengalaman terhadap kejadiankejadian yang menimpa kaum disabilitas dalam kenyataanya bertentangan dengan jaminan yang sudah ditentukan dala peraturan perundang-undangan. Dibeberapa kasus pendampingan, penyandang disabilitas sering kali menjadi korban seperti pemerkosaan dan bentuk pelanggaran hukum laiinya. Dalam proses di pengadilan, korban tunarungu, tunagrahita, atau tunanetra seringkali dianggap tidak cakap hukum karena kesulitan berkomunikasi, atau karena kesaksian yang dianggap meragukan karena fungsi fisik yang terhambat. Dalam situasi ini, kapasitas hukum mereka telah "didisabilitaskan" oleh prosedur dan kerangka logika hukum yang telah gagal membaca keberadaan mereka sebagai subjek hukum yang setara. ${ }^{3}$ Dari latar belakang masalah tersebut menarik bagi penulis untuk membuat karya ilmiah dengan judul "Pengaturan Advokasi Hakhak Penyandang Disabilitas terhadap Diskriminasi dalam Bidang Penegakan Hukum"

3 Ibid., h.256 


\subsection{Rumusan Masalah}

Dari latar belakang masalah tersebut makadalamtulisaninipenulismengemukakan dua rumusan masalah yakni:

1. Bagaimana pengaturan kesetaraan penyandang disabilitas dalam peraturan perundnag-undangan.

2. Bagaimana kesetaraan penyandang disabilitas di depan hukum.

\subsection{Tujuan Penelitian}

Penelitian tentang Pengaturan

Advokasi Hak-Hak Penyandang Disabilitas terhadap Diskriminasi di Bidang Penegakan Hukum mempunyai Tujuan Umum dan Tujuan Khusus.

1. Tujuan Umum : Untuk mengetahui pengaturan mengenai hak-hak penyandang disabilitas dalam peraturan perundang-undangan.

2. Tujuan Khusus: Tujuan Khusus dari Penelitian ini berkaitan dengan Science As a Product yaitu mendeskripsikan dan menganalisis secara mendalam tentang pengaturan advokasi hakhak penyandang disabilitas terhadap diskriminasi dalam penegakan hukum.

\section{Metode Penelitian}

\subsection{Jenis penelitian}

Jenis penelitian yang digunakan dalam penulisan ini adalah jenis penelitian hukum normatif karena meneliti asas-asas serta kaidah hukum. Asas-asas serta kaidah hukum dalam peraturan perundang-undangan yang mengatur mengenai hak-hak asasi manusia serta dalam kovensi-kovensi internasional berkaitan dengan diskriminasi hak-hak penyandang disabilitas dalam penegakan hukum.

\subsection{Sifat Penelitian}

Penelitian mengenai pengaturan advokasi terhadap hak-hak penyandang disabilitas terhadap diskriminasi dalam bidang penegakan hukum adalah bersifat deskriptif kualitatif yaitu mengambarkan situasi, kondisi, dari penyandang disabilitas dalam menghadapi kasus hukum kemudian dikaitkan dengan peraturan perundangundangan yang mengatur mengenai hak-hak penyandang disabilitas.

\subsection{Sumber Bahan Hukum}

Sumber bahan hukum yang dipergunakan dalam penelitian ini meliputi bahan hukum primer berupa peraturan perundang-undangan yang terkait dengan pengaturan hak-hak asasi manusia yakni dalam UUD NRI 1945, UU No.39 Tahun 1999 tentang HAM, Kovensi penyandang Disabilitas. Sumber bahan hukum sekunder berupa bahan hukum yang dapat memberikan penjelasan mengenai bahan hukum primer, seperti hasil-hasil penelitian, hasil karya ilmiah dibidang hukum, literature hukum dan sebagainya. Bahan hukum tersier berupa kamus dan buku pegangan (hand out $)^{4}$

\subsection{Teknik Pengumpulan Bahan}

Metodepengumpulan bahanhukumnya diperoleh melalui metode pengumpulan bahan dengan cara mengumpulkan peraturan

Soerjono Soekanto, 2006, Pengantar Penelitian Hukum, UI Press, Jakarta, h.52 
perundang-undangan, kovensi-kovensi internasional, literature-literatur, jurnal hukum, ${ }^{5}$ dan lain sebagainya yang terkait dengan permasalahan hak-hak asasi manusia kemudian dilanjutkan dengan penyortiran bahan-bahan tersebut yang terkait dengan permasalahan.

\subsection{Teknik Pengolahan dan Analisis Bahan Hukum}

Teknik pengolahan bahan hukum dalam penelitian ini dengan mengolah bahan hukum secara kualitatif artinya bahan-bahan hukum yang relevan diolah dengan melihat kualitas kegunaan.

\section{HASIL DAN PEMBAHASAN}

\subsection{Hak Penyandang Disabilitas Menurut Konvensi Hak Penyandang Disabilitas}

Penyandang disabilitas merupakan istilah pengganti dari penyandang cacat yang sejak dulu banyak digunakan. Penyandang cacat dibagi dalam beberapa kategori sesuai dengan jenis kecacatannya. Mereka dengan gangguan penglihatan disebut tunanetra, yang memiliki hambatan pendengaran dan wicara disebut tunarungu wicara, yang memiliki keterlambatan mental disebut tunagrahita, yang memiliki cacat fisik disebut tunadaksa. Istilah tunalaras yang digunakan untuk mereka dengan gangguan perilaku. Penyandang disabilitas adalah mereka yang mempunyai kecacatan fisik, mental, atau psikososial. Masyarakatsering menggunakan

Johny Ibrahim, 2005, Teori dan Metodologi Penelitian Hukum Normatif, Bayu Media, Malang, h.284 istilah penyandang cacat. Definisi dan kategorisasi inilah yang digunakan UU No. 4 Tahun 1997 tentang Penyandang Cacat. Istilah penyandang cacat (persons with disabilities) resmi mulai digunakan di Indonesia sejak ratifikasi the Unites Nations Convention Rights Persons with Disabilities yang selanjutnya disebut UN CRPD . Arti resmi yang dipakai dalam ratifikasi adalah penyandang Disabilitas. Konvensi tersebut mendefenisikan persons with disabilities sebagai mereka yang memiliki kerusakan fisik, mental, intelektual, atau sensorik jangka panjang yang dalam interaksinya dengan berbagai hambatan dapat merintangi partisipasi mereka dalam masyarakat secara penuh dan efektif. Berkaitan dengan asas kesetaraan, definisi ini menempatkan disabilitas sebagai suatu bentuk keterbatasan dari hasil interaksi antara keterbatasan fungsi fisik atau mental dengan faktor lingkungan, respon sosial, serta faktor yang lebih luas yang mendukung hambatan atas ketidakmampuan tersebut dalam melakukan suatu tindakan dalam wujud apapun.

Keseluruhan isi kovensi tidaklah mengatur hal baru dalam pemenuhan hakhak penyandang disabilitas. Pada dasarnya, semua hak dimiliki oleh manusia juga berlaku setara bagi penyandang disabilitas. Faktanya masyarakat dengan disabilitas merupakan kelompok yang minoritas secara jumlah dan representasi, serta tersubordinasi karena stigma, tingkat pemahaman, serta dominasi politik di tingkat masyarakat dan negara yang mmberikan akses terbatas terhadap penyandang disabilitas. Kovensi ini 
merupakan penegasan yang mengharuskan negara mengambil langkah-langkah nyata dalam upaya penghormatan, pemajuan, serta pemenuhandanperlindunganhakpenyandang disabilitas. Ada beberapa hal penting dari kovensi ini yang layak dipahami dalam proses advokasi penyandang disabilitas, yakni Penghormatan atas martabat yang melekat, otoritas individual termasuk kebebasan untuk menentukan pilihan, dan kemandirian setiap orang termasuk penyandang disabilitas. Pengormatan disini menegaskan bahwa penyandang disabilitas memiliki kelayakan untuk mengatur tata kehidupannya sendiri tanpa perlu diintervensi oleh pihak manapun sebagai suatu penghormatan terhadap hak asasi penyandang disabilitas.

Prinsip Nondiskriminasi berarti bahwa setiap warga masyarakat termasuk penyandang disabilitas berhak untuk diperlakukan sama seperti seorang yang tidak berkebutuhan khusus pada umumnya, dalam setiap bentuk perlakuan yang adil, merata, tidak menempatkan penyandang disabilitas ke dalam suatu perkecualian. Prinsip partisipasi dan keterlibatan penuh dan efektif dalam masyarakat merupakan salah satu bentuk upaya penstabilan atau pengakuan terhadap penyandang disabilitas, bawasannya seorang yang dianggap memiliki suatu keterbatasan masih diakui partisipasinya serta dilibatkan secara penuh dalam pembangunan masyarakat. Prinsip yang paling penting dalam kovensi tersebut yakni penghormatan atas perbedaan dan penerimaan para penyandang disabilitas sebagai bagian dari keragaman manusia dan rasa kemanusiaan serta penghormatan atas kapasitas yang berkembang dari anak penyandang disabilitas dan hak-hak penyandang disabilitas untuk melindungi identitas mereka merupakan prinsip-prinsip umum dari kovensi tersebut yang berkenaan langsung dengan keberadaan penyandang disabilitas. Pada realitasnya tidak sedikit anak penyandang disabiltas memiliki potensi melebihi seorang yang normal misalnya dari segi kemampuan menghasilkan suatu karya yang bernilai ekonomi, serta tidak kurang juga memiliki kemampuan untuk mengahsilkan pendapatan dengan segala bentuk keterbatasan. Hak penyandang disabilitas dalam kovensi tersebut berupa:

a. Kesetaraan dan nondiskriminasi, negara pihak wajib memastikan terwujudnya kesetaraan dengan cara:

1. Larangan atas diskriminasi atas dasar kecacatan, serta menjamin perlindungan hukum dari bentuk diskriminasi apapun.

2. Mengedepankan kepentingan anak dengan disabilitas dalam menentukan berbagai hal.

3. Menjamin kebebasan anak dengan disabilitas dalam mengemukakan pendapat mengenai hal yang mempengaruhi kehidupan mereka, menjadikannya sebagai dasar pertimbangan sesuai dengan tingkat kematangan dan kedewasaan mereka, serta menjamin ketersediaan bantuan sesuai dengan tingkat usia dan disabilitas mereka. 
b. Pengakuan yang setara di hadapan hukum

Penyandang disabilitas memiliki hak atas pengakuan dihadapan hukum. Negara pihak harus mengakui bahwa penyandang disabilitas berhak menikmati kapasitas legal atas dasar kesetaraan, dan menyediakan akses terhadap dukungan yang dibutuhkan untuk melaksanakan kapasitas legal para penyandang disabilitas. Hal ini berorientasi pada penghormatan terhadap setiap manusia dalam keadaaan atau keterbatasan apapun, untuk mewujudkan keadilan sosial yang sesuai dengan nilai-nilai kemanusiaan dalam rangka menjamin kesetaraan daam berbagai bidang kehidupan. Pengakuan yang setara dihadapan hukum memiliki nilai besar terhadap pengakuan bahwa penyandang disabilitas juga layak mendapatkan suatu perhatian yang besar karena faktor-faktor kekurangan yang dimiliki. Sehingga perlindungan terhadap penyandang disabilitas seharusnya menjadi hal yang prioritas.

\subsection{Kesetaraan di Muka Hukum bagi Penyandang Disabilitas}

Dalam perkembangannya, HAM menempatkan isu disabilitas sebagai bagian integral dari HAM. Hal tersebut berkenaan dengan hak-hak dasar sebagai mahluk ciptaan tuhan dalam bentuk pemberian kehidupan serta hak-hak lain yang melekat dalam diri manusia tidak ada pembedaan satu sama lain, mewajibkan setiap manusia untuk saling menghormati hak-hak asasi manusia satu dengan yang lainnya termasuk penyandang disabillitas. Anggapan bahwa penyandang disabilitas tidak mempunyai hak atau menjalankan hak sebagaimana seharusnya dengan alasan keterbatasan yang dimiliki merupakan bentuk penyimpangan yang bermuara pada diskriminasi terhadap penyandang disabilitas. Langkah-langkah pemenuhan hak-hak dasar sebagaimana diatur dalam instrument HAM dan untuk kelompokpenyandang disabilitas berlakuUN CRPD yang semestinya juga memperhatikan prinsip interdependence, indivisibility, dan interlated of rights, ${ }^{6}$ yaitu terhadap setiap hak saling berhubungan, saling melengkapi, serta tidak dapat dipecah oleh siapapun.

Berdasarkan pemikiran tentang kontrak sosial, UUD 1945 dianggap tidak berbicara tentang HAM karena UUD menganut logika terbalik dan hanya mengatur hak warga Negara. ${ }^{7}$ Dengan kata lain, manusia Indonesia sudah ada lebih dulu dengan hakhak dasarnya sebagai manusia Indonesia. Manusia Indonesiainibersepakatmembentuk Negara Indonesia sebagai sebuah mekanisme penyelenggaraan kepentingan umum. Ketika menyelenggarakan kepentingan manusia Indonesia, maka pemerintahan Negara harus mengacu kepada hak-hak dasar manusia Indonesia. Kemanusiaan manusia diakui sebagai consensus universal yang justru tetap melekat sebagai pemilik asasi mutlak atas dasar kemanusiaan, terlepas dari perbedaan jenis kelamin, warna kulit, status ekonomi, kewarganegaraan, agama, dan lain-lain. ${ }^{8}$

YLBHI, Op.Cit. h.256

Marianus Kleden, 2008, Hak Asasi Manusia dalam Masyarakat Komunal, Lamalera, Yogyakarta, h. 76 Majda El-Muhtaj, 2005, Hak Asasi Manusia dalam Konstitusi Indonesia, Kencana Prenada Media Group, Jakarta, h. 41 
Secara umum, hak-hak penyandang disabilitas yang potensial dilanggar oleh penyidik dan hakim meliputi hak di depan hukum (equality before the law) dan hak atas peradilan yang adil (right to a fair trial). Sebagai contoh, hak penyandang disabilitas netra atas persamaan dihadapan hukum dan hak atas kesetaraan dan nondiskriminasi. Hak ini terlanggar ketika penyidik tidak mau melakukan penyelidikan atau penyidikan kasus perkosaan, kekerasan seksual, kesusilaan atau perbuatan cabul yang menimpa tunanetra sebagai korban karena memiliki keterbatasan penglihatan. Penyidik sulit atau ragu untuk mempercayai keterangan atau laporan korban sekalipun sudah ada visum at refertum, atau alat bukti lain yang setara. Dalam proses pengadilan, hak seorang penyandang disabilitas atas peradilan yang adil terlanggar jika hakim tidak mau menerima kesaksian korban karena tidak bisa dikualifikasikan sebagai saksi yang melihat sendiri perkara pidana. ${ }^{9}$

Diskriminasi menurut W.J.S. Poerwadarminta dalam Kamus Umum Bahasa Indonesia merupakan suatu tindakan pembedaan perlakuan terhadap sesama warga Negara (berdasarkan perbedaan warna kulit, suku, agama, dan sebagainya. ${ }^{10}$ Dalam kasus perkosaan, kekerasan seksual, kesusilaan atau perbuatan cabul yang menimpa tuna rungu atau tunawicara sebagai korbanm penyidik tidak menerima kesaksian korban melalui bahasa isyarat. Bila pendamping

10 W.J.S. Poerwadarminta, 2007, Kamus Umum Bahasa Indonesia, Balai Pustaka, Jakarta, h.297 minta penerjemah, penyidik tidak memenuhi karena tidak ada aturannya dalam KUHAP. Penyidik juga jarang yang memiliki juga jarang yang memiliki kemampuan memahami bahasa isyarat. Di persidangan, hakim juga ragu apakah kesaksian korban memang benar atau salah. Kalaupun didatangkan ahli, hakim masih juga ragu karena korban tidak bisa mendengar. Jika haim mempercayai penerjemah, tidak semua orang mau jadi penerjemah. Penegakan hukum yang sebenarnya merupakan barometer berlangsungnya kehidupan ketatanegaraan bangsa Indonesia, baik itu yang memiliki implikasi terhadap tatanan budaya, sosial, dan ekonomi menjadi terganggu, karena perspektif penegakan hukum yang labilitas. ${ }^{11}$ Penegakan hukum yang demikian menyebabkan runtuhnya kepercayaan terhadap hukum sebagai suatu ujung tombak keadilan dalam kehdiupan berbangsa dan bernegara.

Peranan negara yang memberikan perlindungan dan kesejahteraan warga masyarakat Indonesia harus mampu diwujudkan dalam realita. ${ }^{12}$ Salah satu permasalahan yakni berkaitan dengan perlakuan yang sama di hadapan hukum berarti bahwa penyandang disabilitas dalam menghadapi kasus hukum berhak mendapatkan seseorang yang mampu mewakiliataumengartikanapayangdimaksud misalnya oleh penyandang disablitas tuna

11 Indriyanto Seno Adji, 2009, Humanisme dan Pembaruan Penegakan Hukum, Kompas, Jakarta, h. 237

12 Satjipto Rahardjo, 2012, Hukum Progressif, Pustaka Rizki Putra, Semarang, h.34 
rungu, tuna netra, dan lain sebagainya. Berhak didengar dan dicatat segala keterangannya di tiap-tiap tahap peradilan pidana, hak untuk sidik oleh penyidik yang memiliki kemampuan memahami bahasa isyarat dan hak atas peradilan yang jujur dan tidak memihak. Begitu penting kedudukan perlakuan terhadap penyandang disabilitas yang menghadapi kasus hukum, memang dibenarkan sejumlah peraturan perundangperundangan memuat hak tersebut. salah satunya dalam instrument hukum internasional yakni dalam International Covenan on Civil and Political Rights/ ICCPR) menentukan:

\section{Article 26}

All persons are equalbefore the law and are entited without any discrimination to the equal protection of the law. In this respect, the law shall prohibit any discrimination and guarantee to all persons equal and effective protection against discrimination on any ground such as race, colour, sex, language, religion, political or other opinion, national or social origin, property, birth or other status. ${ }^{13}$ (mengatur setiap orang sama di hadapan hukum dan berhak atas perlindungan hukum yang sama tanpa diskriminasi apapun).

Dari ICCPR tersebut penyandang disabilitas telah secara tegas harus sama kedudukannya di dalam hukum manakala mengahadapi kasus hukum bebas dari perlakuan diskriminasi dalam bentuk

13 Sarah Joseph, Jenny Schultz, and Melissa Castan, 2004, The International Covenant on Civil and Political Rights, Oxpord University Press, New York, p.679 apapun. Banyak penanganan kasus yang melibatkan orang dengan disabilitas, ketika proses Berita Acara Pemeriksaan (BAP) telah selesai, tim pendamping kasus telah mengantisipasi akan adanya permasalahan ini dikalangan hakim. Bentuk antisipasinya adalah dengan cara mengkomunikasikan kondisi dan keterbatasan korban, kemungkinan-kemungkinan ini akan berdampak menyulitkan terhadap proses persidangan, serta menawarkan solusi komunikasi yang memungkinkan serta sumber-sumber dukungan yang bisa membantu seperti menyediakan penerjemah. Keberadaan sekolah yang terbiasa menangani penyandang disabilitas serta organisasi penyandang disabilitas sangat membantu untuk menyediakan dukungan terkait dengan disabilitas korban, seperti menyediakan penerjemah, serta dukungan moral. Penyidik juga memiiki keengganan untuk memproses penyidik perkara pelanggaran hukum seperti perkosaan, kekerasan seksual, kesusilaan atau perbuatan cabul yang menimpa penyandang disabilitas mental dan intelektual karena memiiki kecerdasan di bawah rata-rata. Disabilitas mental dan intelektual dengan bantuan pendamping yang melaporkan perkara pidana yang menimpanya dianggap sebagai orang gila oleh penyidik sehingga tidak layak dijadikan saksi.

Dipersidangan, hakim menganggap keterangan saksi tidak layak dijadikan sebagai alat bukti karenamemiliki kecerdasan di bawah rata-rata, padahal untuk menjadi saksi haruslah orang yang mampu mengingat dengan baik kejadian yang didengar, dilihat 
atau dialami. Penyandang disabilitas yang menjadikorbanperkosaan,kekerasanseksual, kesusilaan atau perbuatan cabul juga ditolak kesaksiannya oleh penyidik karena seringkali menjawab dengan jawaban yang sama atas pertanyaan-pertanyaan yang diajukan penyidik. Penyidik juga tidak mendatangkan ahli untuk memperkuat kesaksian korban. Di persidangan, hakim meragukan keterangan saksi korban yang lambat merespon pertanyaan hakim. Hal tersebut tidak semestinya terjadi jika penyidik dan hakim mempunyai perspektif tentang disabilitas yang mencukupi. Dalam situasi-situasi semacam inilah, keberadaan pendamping kasus seperti paralegal, pengacara, atau organisasi-organisasi bantuan hukum untuk aktif memberikan pemahaman terhadap para aparat penegak hukum, dengan bekerja sama dengan organisasi penyandang disabilitas menjadi sangat signifikan pengaruhnya.

Perlakuan yang nondiskriminatif sebagai kelanjutan dari hak atas perlakuan yang sama dihadapan hukum bagi penyandang disabilitas dapat terwujud melalui pelaksanaan hak atas peradilan yang adil. Terdapat dua hal yang pokok yang merupakan inti dari hak ini yakni jaminan hak atas akses pada peradilan yang efektif bagi penyandang disabilitas. Akses ini berupa kemudahan yang diberikan bagi penyandang disabilitas dari awal proses penegakan hukum sampai dengan putusan pengadilan dalam bentuk bantuan berupa perwakilan-perwakilan yang didengar keterangannya dalam tiap tahapan sistem peradilan pidana. Kemudian hal pokok yang kedua aparat penegak hukum dituntut untuk memiliki kemampuan yang terkait dengan hak-hak penyandang hal ini berarti bahwa penegak hukum harus mempunyai kemampuan yang lebih yang mengerti apa yang dimaksudkan oleh penyandang disabilitas, sehingga mekanisme penegakan hukum dapat berlangsung dengan adil dan tanpa diskriminasi.

Uraian mengenai dasar normatif hak atas perlakuan yang sesuai, dalam proses peradilan yang adil perlu dijadikan sebagai basis legal advokasi bagi penyandang disabilitas yang menjadi korban kejahatan dan berhadapan dengan sistem peradilan pidana. Tindakan penyidik yang menolak untuk menyidik perkara pidana karena korbannya adalah orang tidak yang mampu melihat (tunanetra), jelas melanggar hak atas perlakuan atas nondiskriminatif. Sekalipun korbannyaadalah tunanetra dan penyidikragu untuk mempercayai keterangan atau laporan korban, penyidik wajib untuk melakukan penyidikan. Hal ini KUHAP memandang keterangan saksi korban hanya merupakan satu dari lima alat buktti yang diakui seperti keterangan ahli, surat, petunjuk, dan keterangan terdakwa. Artinya, tanpa adanya keterangan saksi korban pun, penyidik tetap wajib menyidik perkara tersebut. Bukti berupa visum et repertum dari suatu rumah sakit bahwa saksi korban tunanetra memang telah diperkosa atau dicabuli, sudah cukup untuk melanjutkan proses penyidikan.

Kepemimpinan aparat penegak hukum sangat ditentukan oleh sikap pemimpin harus mempunyai ketegasan yang berwujud 
dalam sikap yang konsisten, mempunyai komitmen, dan selalu mempunyai dorongan untuk mempunyai sikap berkompeten dalam penegakan hukum. ${ }^{14}$ Usaha penegakan hukum tertentu telah menimbulkan banyak keresahan. Khususnya yang diperhatikan adalah praktek-praktek penegakan hukum dilingkungan Kepolisian, Kejaksaan, Pengadilan, dan Lembaga Pemasyarakatan. Tidak dapat disangkal bahwa usaha penegakan hukum itu merupakan masalah yang kompleks dan selalu menimbulkan permasalahan lebih lanjut karena beberapa hal tertentu. Usaha penegakan hukum kerapkali dilakukan berdasarkan kemauan dan tujuan yang baik, tetapi kerapkali pelaksanaanya malahan menimbulkan akibat-akibat yang tidak diinginkan yang merugikan, yang menimbulkan korban fisik, mental dan sosial.

Dalam persidangan tindakan hakim yang menolak kesaksian saksi korban tunanetra hanya karena tidak melihat juga merupakan pelanggaran terhadap hak atas perlakuan yang sama di hadapan hukum dan bebas dari perlakuan yang diskriminatif. Sekalipun saksi korban orang tidak bisa melihat karena penyandang disabilitas, hakim seharusnya tetap melakukan pemeriksaan dipengadilan seperti halnya dengan seseorang yang normal. Hal ini membawa konsekuensi bahwa masih sering terjadi tindakan yang bersifat diskriminatif dalam penegakan hukum sehingga diperlukan langkah-langkah

14 Siswanto Sunarso, 2005, Wawasan Penegakan Hukum di Indonesia, Citra Aditya Bakti, Bandung, h.100 untuk mencegah perilaku diskriminatif terhadap penyandang disabilitas dalam penegakan hukum. Peraturan perundangundangan telah secara tegas menjamin persamaan hak bagi penyandang disabilitas. Dengan demikian dalam realitasnya tidak sedikit penyandang disabilitas yang masih mengalami diskriminasi dalam penegakan hukum selama ini.

\section{SIMPULAN DAN SARAN \\ 1. Simpulan}

Berdasarkan uraian tersebut dapat disimpulkan bahwa penyandang disabilitas mempunyai hak yang sama dengan manusia normal lainnya yang diakui dalam peraturan perundang-undangan baik nasional maupun internasional sebagai bagian dari Hak Asasi Manusia. Penyandang disabilitas memiliki hak yang sama dalam berbagai bidang kehidupan termasuk dibidang penegakan hukum, penyandang disabilitas harus ditangani secara khusus untuk menghindari tindakan-tindakan diskriminasi sehingga jaminan perlindungan hukum terhadap semua orang dapat diwujudkan.

\section{Saran}

Diskriminasi dan ketidakadilan berbasis disabilitas masih sering terjadi, baik yang sifatnya structural maupun kultural, maka harapannya agar ada lebih banyak pembela hak-hak penyandang disabilitas yang mampu memberikan perlindungan secara nyata terhadap penyandang disabilitas jika menghadapi kasus hukum untuk mewujudkan keadilan sosial dan kesetaraan di depan hukum. 


\section{DAFTAR PUSTAKA}

\section{Buku}

Amiruddin dan H. Zainal Asikin, 2003, Pengantar Metode Penelitian Hukum, Raja Grafindo Persada,Jakarta

Arief Gosita, 2009, Masalah Korban

Kejahatan, Universitas Trisakti, Jakarta.

Indriyanto Seno Adji, 2009, Humanisme dan Pembaruan Penegakan Hukum, Kompas, Jakarta.

Majda El-Muhtaj, 2005, Hak Asasi Manusia dalam Konstitusi Indonesia, Kencana Prenada

Marianus Kleden, 2008, Hak Asasi Manusia dalamMasyarakatKomunal,Lamalera, Yogyakarta Media Group, Jakarta

Peter Mahmud Marzuki, 2005, Penelitian Hukum, Kencana Prenada, Jakarta

Sarah Joseph, Jenny Schultz, and Melissa Castan, 2004, The International Covenant on Civil and Political Rights, Oxpord University Press, New York

Satjipto Rahardjo, 2012, Hukum Progressif, Pustaka Rizki Putra, Semarang

Soerjono Soekanto, 2006, Pengantar Penelitian Hukum, UI Press, Jakarta

W.J.S. Poerwadarminta, 2007, Kamus Umum Bahasa Indonesia, Balai Pustaka, Jakarta

YLBHI, 2014, Panduan Bantuan Hukum di Indonesia, Yayasan Obor Indonesia, Jakarta

\section{Perundang-undangan}

International Covenan on Civil and Political Rights (ICCPR)

UU No. 19 Tahun 2011 tentang Pengesahan Convention on the Rights of persons with Disbilities.

UU No.39 Tahun 1999 tentang Hak Asasi Manusia.

UU No.4 Tahun 1997 tentang Penyandang Cacat 